\title{
Synchronous Onset of NGF and TrkA Survival Dependence in Developing Dorsal Root Ganglia
}

\author{
Fletcher A. White, ${ }^{1}$ Inmaculada Silos-Santiago, ${ }^{2}$ Derek C. Molliver, ${ }^{1}$ Merry Nishimura, ${ }^{3}$ Heidi Phillips, ${ }^{3}$ \\ Mariano Barbacid, ${ }^{2}$ and William D. Snider ${ }^{1}$ \\ ${ }^{1}$ Center for the Study of Nervous System Injury, Department of Neurology, Washington University School of Medicine, St. \\ Louis, Missouri 63110, ${ }^{2}$ Bristol-Myers Squibb, Princeton University, Princeton, New Jersey 08543, and ${ }^{3}$ Genentech Inc., \\ South San Francisco, California 94080
}

\begin{abstract}
Determinations of dorsal root ganglion (DRG) neuron loss in nerve growth factor (NGF) and neurotrophin-3 (NT-3) null mutant mice have supported the concept that neurons can switch neurotrophin dependence by revealing that many neurons must require both of these factors acting either sequentially or simultaneously during development. The situation is complex, however, in that $N T-3(-/-)$ mutant mice show far greater neuron loss than mice deficient in the NT-3 receptor TrkC, suggesting that NT-3 may support many DRG neurons via actions on the NGF receptor TrkA. To assess the possibility of ligand-receptor cross-talk as a developmental mechanism, we have compared the onset of survival dependence of lumbar DRG neurons on NT-3, TrkC, NGF, and TrkA signaling in mice deficient in these molecules as a result of gene targeting. At embryonic day 11.5 (E11.5), virtually all lumbar DRG cells express TrkC mRNA and many require NT-3 and TrkC signaling for survival. In contrast,
\end{abstract}

although many lumbar DRG cells also express TrkA at E11.5, there is little survival dependence on TrkA signaling. By E13.5, most lumbar DRG cells have downregulated TrkC mRNA. The onset of survival dependence on NGF and TrkA-signaling is concurrent and of equal magnitude at E13.5, demonstrating that NT-3 alone does not support DRG neurons via TrkA, nor can NT-3 compensate for the loss of NGF. We conclude that many murine DRG cells require NT-3 for survival before exhibiting NGF dependence and that NT-3 activation of TrkA is unimportant to these early NT-3 survival-promoting actions. We suggest that the discrepancy in cell loss between NT-3(-/-) and $\operatorname{trkC}(-/-)$ mutants is attributable to the ability of NT-3 to support DRG neurons via TrkA in the artificial situation where TrkC is absent.

Key words: NGF; NT-3; TrkA; TrkC; DRG development; naturally occurring cell death
Mice with targeted mutations in neurotrophin and the Trk family of receptor tyrosine kinase genes have established that many classes of peripheral neurons require a target-derived neurotrophin for survival at some stage of development (for reviews, see Snider, 1994; Klein, 1994; also see Ernfors et al., 1995, and references therein). These results substantiate ideas about target dependence of peripheral neurons during critical developmental periods based on nearly three decades of work with the prototypical neurotrophin nerve growth factor (NGF). Although the dependence of peripheral neurons on target-derived neurotrophins is now established, recent work in vitro suggests that neurons and even neuronal precursors may require neurotrophins for survival before the acquisition of growth factors from target fields. For example, dissociated murine trigeminal sensory neurons require brain-derived neurotrophic factor (BDNF) or neurotrophin-3 (NT-3) as early as E11 and then switch to NGF dependence by E13 (Buchman and Davies, 1993). Furthermore, sympathetic neuroblasts express TrkC and are supported by NT-3 in vitro at early developmental stages, whereas sympathetic ganglion neurons express TrkA and require NGF later in development (Birren et al., 1993; DiCicco-Bloom et al., 1993). An idea that has emerged from

Received March 18, 1996; revised May 10, 1996; accepted May 13, 1996.

This work was supported by National Institutes of Health Grants NS31768 and PO1-NS17763. We thank John Harding and Ray Gerfen for technical assistance. Helpful comments on this manuscript were provided by Dr. Douglas E. Wright.

Correspondence should be addressed to W. D. Snider, M.D., Center for the Study of Nervous System Injury, Department of Neurology, Box 8111, Washington University School of Medicine, 660 South Euclid Avenue, St. Louis, MO 63110.

Copyright (C) 1996 Society for Neuroscience 0270-6474/96/164662-11\$05.00/0 these studies is that peripheral neurons or their precursors depend on locally synthesized factors before the arrival of axons in target fields and then switch to dependence on a target-derived factor (Bujo-Bello et al., 1994; Davies, 1994). All of these studies would predict that the onset of dependence of dorsal root ganglion (DRG) sensory neurons on NGF/TrkA signaling would occur after axons have arrived in developing skin and that neurons would be dependent on another neurotrophin before that time.

Support for this idea has been generated by examination of DRG neuron survival in the settings of neurotrophin and neurotrophin receptor deficiency in mouse and chick. Most murine DRG neurons require NGF/TrkA signaling at some stage of development, as demonstrated by the loss of $70-80 \%$ of lumbar DRG neurons in animals with mutations in these genes (Crowley et al., 1994; Smeyne et al., 1994; Silos-Santiago et al., 1995). In addition, $N T-3(-/-)$ mice show loss of $50-70 \%$ of lumbar DRG neurons, demonstrating that some NGF-dependent neurons also require NT-3 for survival at some stage of development (Ernfors et al., 1994; Fariñas et al., 1994). Indeed, Gaese and colleagues (1994) demonstrated in chick that NT-3 dependence occurs earlier than NGF dependence and that some DRG neurons seem to require both factors.

Although it now seems clear that NT-3 is important for the survival of some NGF-dependent DRG neurons, a number of issues related to this NT-3 dependence remain unresolved. First, NT-3 has pleiotrophic effects in early development with demonstrable influences on proliferation, migration, survival, and even differentiation of neuronal precursors (Kalcheim et al., 1992; 
Birren et al., 1993; DiCicco-Bloom et al., 1993; Pinco et al., 1993; Verdi and Anderson, 1994; Ockel et al., 1996). Whether the effects of NT-3 deficiency on NGF-dependent DRG neurons are attributable to effects on neuron or precursor survival as opposed to some other mechanism is unknown. Second, the DRG population is heterogeneous, containing TrkC-expressing proprioceptive neurons and TrkA-expressing nociceptors even at early developmental stages (Ernfors et al., 1993; Mu et al., 1993; Tessarollo et al., 1993). Whether these different populations require NT-3 at the same or different developmental stages is unclear. Finally, the situation is complex in that NT-3(-/-) mutants show far greater neuron loss than $\operatorname{trkC}(-/-)$ null mutants. This latter finding has suggested that NT-3 supports many DRG neurons via actions on the NGF receptor TrkA rather than the preferred NT-3 receptor TrkC (Davies, 1994; Fariñas et al., 1994; Klein et al., 1994).

To settle these unresolved issues about the early dependence of sensory neurons on neurotrophins in vivo, we have compared the onset of survival dependence of lumbar DRG neurons on NT-3, TrkC, NGF, and TrkA signaling and determined expression patterns of ligands and receptors in relation to the initial target encounter of sensory axons.

\section{MATERIALS AND METHODS}

Animals. The generation of the NGF and Trk null mutant mice used in this study has been described (NGF, Crowley et al., 1994; trkA, Smeyne et al., 1994; trkC, Klein et al., 1994). NT-3(-/-) mice (Ernfors et al., 1994) were obtained from Jackson Laboratory (Bar Harbor, ME). Wildtype (WT), and (-/-) mutants were obtained from the overnight matings [day of vaginal plug $=$ embryonic day 0.5 (E0.5)]. Pregnant females were killed by halothane overdose to harvest embryos on E11.5, E13.5, or E15.5. Staging of embryos was verified by crown-rump length and degree of limb development. The genotyping of mice was performed by polymerase chain replication using primers published in the studies cited above. Embryos were frozen immediately on dry ice and stored at $-80^{\circ} \mathrm{C}$ until use.

Outbred CF-1 (Charles River Labs, Wilmington, MA) mouse embryos were used to supplement the in situ hybridization and immunocytochemistry analyses because of the greater availability of these animals. In preliminary comparisons of size and maturity at various embryonic stages and time course of (1) TrkA and TrkC receptor expression in DRGs, (2) neurotrophin expression in limb bud, (3) axon projections to spinal cord and periphery, and (4) time course of naturally occurring cell death, no gross differences were noted between trkA $(+/+)$ mice and outbred CF-1s.

In situ hybridization. RNA probes complementary to neurotrophin and neurotrophin receptor mRNAs were synthesized from full length cDNAs or cDNA fragments. The following probes were used: (1) SD18-TrkA (rat), 345 bp, extracellular domain; (2) SD36-TrkC (rat), 577bp, extracellular domain; (3) SD39-NGF (rat), 771bp, pre-pro-NGF; (4) SD79NGF (mouse), 807bp, NGF short transcript; and (5) SD70-NT-3 (mouse), $783 \mathrm{bp}$, full length. To synthesize antisense and sense riboprobes, plasmids were linearized with the appropriate restriction endonucleases and transcribed in vitro in the presence of $90 \mathrm{mCi}\left[{ }^{33} \mathrm{P}\right] \mathrm{UTP}$ (Amersham, Arlington Heights, IL).

Previously frozen and embedded embryos were sectioned transversely at $20 \mu \mathrm{m}$ through the hindlimb region, mounted on SuperFrost/Plus slides (Fisher Scientific, Orangeburg, NY), and allowed to air-dry. On the day of hybridization, slides were equilibrated to room temperature (RT), fixed for $10 \mathrm{~min}$ in $4 \%$ paraformaldehyde in $0.1 \mathrm{~m}$ isotonic PBS, $\mathrm{pH} 7.4$, and then rinsed twice in PBS (5 min each). In situ hybridizations were performed according to a previously published protocol (Wright and Snider, 1995). Slides were then dipped in Kodak NTB-2 liquid emulsion and stored in desiccated light-tight boxes at $4^{\circ} \mathrm{C}$ for $10-15 \mathrm{~d}$. Slides were developed in Kodak D-19 and fixed in Kodak Fixer, rinsed in distilled water, and counterstained with hemotoxylin and eosin.

Control experiments were performed to assess the specificity of the riboprobes. Sections were incubated with individual sense-strand ${ }^{33} \mathrm{P}$ labeled riboprobes or were pretreated with RNaseA (Boehringer Mannheim, Mannheim, Germany) $\left(20 \mu \mathrm{g} / \mathrm{ml}\right.$ for $30 \mathrm{~min}$ at $\left.37^{\circ} \mathrm{C}\right)$, followed by hybridization with individual antisense riboprobes. In each case, control hybridizations resulted in loss of the specific hybridization patterns noted with the complementary RNA probes.

Immunohistochemistry. WT embryos were immersion-fixed in $3 \%$ paraformaldehyde $15 \%$ picric acid in $0.1 \mathrm{~m}$ phosphate buffer, $\mathrm{pH} 7.4$, for $2 \mathrm{hr}$. They were then placed in $30 \%$ sucrose overnight and frozen in OCT embedding medium on dry ice. Embedded embryos were sectioned transversely at $20 \mu \mathrm{m}$ through the hindlimb region, mounted on Fisher SuperFrost/Plus slides, and allowed to air-dry. Fixed and mounted cryosections were encircled with a Teflon coating using a Pap pen (Kyota International, Elk Grove Village, IL) and incubated for $1 \mathrm{hr}$ in a blocking solution consisting of Superblock buffer (Pierce Chemical, Rockford, IL), $0.3 \%$ Triton X-100, 0.3\% Tween 20 (Electron Microscopy Sciences, Fort Washington, PA), $1.0 \%$ porcine gelatin (Sigma, St. Louis, MO), and $1.5 \%$ normal serum. This solution was diluted 1:1 with Superblock buffer $/ 1.5 \%$ normal serum and used for the dilution of primary and secondary antibodies. Rtk-Ex, a polyclonal antibody generated against the extracellular domain of TrkA (Clary et al., 1995), was generously provided by Dr. Louis F. Reichardt (University of California San Francisco) and used at a dilution of 1:8000. Sections were incubated in the primary antibody overnight (12-16 hr). Slides were then washed three times (5 min each) with PBS and visualized with the indirect HRP-DAB reaction using a Vectastain Elite kit (Vector, Burlingame, CA) as per instructions. Slides were dehydrated in a graded series of alcohols and coverslipped in xylene with DPX mountant medium.

Camera lucida drawings of the complete innervation patterns were made during the stages of initial limb innervation in adequately labeled preparations (E11.5, $n=2$; E13.5, $n=3$; E15.5, $n=2)$. Tracings from serial $40 \mu \mathrm{m}$ sections were superimposed. In some preparations, TrkA immunohistochemistry was compared with DiI (Molecular Probes, Eugene, OR) staining of DRG axons to assess the adequacy of TrkA staining. DiI was applied and visualized as described previously (Wright et al., 1995).

In situ apoptosis detection. Unfixed tissue cryosections were fixed in $10 \%$ neutral buffered formalin for $10 \mathrm{~min}$ at RT followed by three washes in PBS (5 min for each wash), according to the manufacturer's instructions (Oncor, Gaithersburg, MD). Sections were postfixed in ethanolacetic acid $(2: 1)$ for $5 \mathrm{~min}$ at $-20^{\circ} \mathrm{C}$ and washed with PBS $(3 \times 5 \mathrm{~min}$ each) at RT. A preincubation buffer was applied to tissue sections for 10 $\min$. Sections were then incubated with working strength terminal transferase at $37^{\circ} \mathrm{C}$ in a humidified chamber for $1 \mathrm{hr}$. After primary incubation, tissue sections were incubated with intermittent agitation in a stop-wash buffer at $37^{\circ} \mathrm{C}$ for $30 \mathrm{~min}$, followed by $3 \mathrm{PBS}$ washes for $5 \mathrm{~min}$ each. Fifty microliters of antidigoxigenin-peroxidase were applied to slides, covered with parafilm, and incubated in a humidified chamber at RT for $2 \mathrm{hr}$. Parafilm was removed, and sections were washed in PBS $(3 \times 5 \mathrm{~min})$. Slides were then washed 3 times (5 min each) with PBS and visualized with the indirect HRP-DAB reaction. The numbers of animals of each genotype studied at each age were as follows: E11.5: $\operatorname{trk} A(-/-)$ (2), $N T-3(-/-)$ (2), $\operatorname{trkC}(-/-)$ (2), WT (5); E13.5: $\operatorname{trk} A(-/-)$ (5), $N G F(-/-)(4), N T-3(-/-)(2), \operatorname{trkC}(-/-)$ (5), WT (8); E15.5: $\operatorname{trk} A(-/-)$ (3), $N G F(-/-)$ (3), WT (4). WT includes $+/+$ mice from all of the neurotrophin and Trk null mutant lines.

Data analysis. Whether a neuron exhibited apoptotic figures (high concentration of DAB-labeled 3'-OH ends of fragmented DNA) was evaluated by examination of tissue sections using a $50 \times$ water-immersion lens. Determination of percentages of apoptosis-positive neurons in lumbar DRGs was performed by counting all apoptotic DRG cells present in at least 10 sections per animal and then estimating the number of cells present in each section by multiplying a reticule count by an area measurement of the individual section. Additionally, counts were made of apoptotic-positive cells in at least 20 lumbar DRG sections per animal, and the mean number of apoptotic figures per section was determined. Mean numbers of apoptotic profiles in all groups of WT mice were similar at each age, and results were therefore combined for statistical analysis. The statistical significance of differences between the average number of apoptotic figures per section in WT and null mutant mice of a given embryonic age was accomplished by means of Student's $t$ tests. The accepted level of significance in all tests was $p<0.01$. Analysis was restricted to lumbar ganglia to correlate findings with expression of neurotrophins in the hindlimb. Although it was difficult to identify particular segmental ganglia at E11.5 and E13.5, we did compare more rostral sections with more caudal sections and found no noticeable differences in the extent of apoptosis at the particular developmental stages studied. 
Determination of cross-sectional areas and cell number. Whole embryonic $\operatorname{trk} A(+/+)$ and $\operatorname{trk} A(-/-)$ mice at E15 were fixed by immersion in $4 \%$ paraformaldehyde in $0.1 \mathrm{M}$ phosphate buffer. Thorax/hindlimb tissue blocks were dehydrated in ethanol, embedded in paraffin, serially sectioned at $10 \mu \mathrm{m}$, deparaffinized, rehydrated, and stained with hemotoxylin and eosin. Areas of lumbar DRG sections were generated from camera lucida drawings of paraffin-embedded ganglia profiles stained with hemotoxylin and eosin. An equal number of ganglia profiles (every sixth section) were taken from each animal ( $n=4$ of each genotype). Cross-sectional areas were determined with the aid of an image analysis system (Bioquant, R \& M Biometrics, Nashville, TN). Cross-sectional areas of cryostat sections were determined in a similar manner at E13.5 for $\operatorname{trk} A(+/+), \operatorname{trk} A(-/-), N G F(+/+)$, and $N G F(-/-)$ mice. Procedures used for DRG cell counting have been described previously (SilosSantiago et al., 1994). Counts in control animals at E17.5 were slightly lower than those reported in the postnatal (PN) period, presumably because of the difficulties in recognizing nuclei at early developmental stages.

\section{RESULTS}

\section{Lumbar DRG neurons require TrkA and NGF signaling at E13.5}

Previously reported results in $N G F(-/-)$ and trkA(-/-) mutant mice have shown that massive DRG neuron loss has already occurred by PN0 (Crowley et al., 1994; Silos-Santiago et al., 1994; Smeyne et al., 1994). To determine when during embryonic development lumbar DRG neurons acquire dependence on TrkA signaling for survival, we performed cell counts and ganglion volume determinations in hindlimb sections of embryos on E17.5 and E15.5. To assess survival at earlier stages (E11.5, E13.5), we sought evidence of apoptosis in lumbar DRGs of trkA(-/-) and $\operatorname{trk} A(+/+)$ animals using terminal transferase labeling to detect oligosomal DNA fragments.

The results of ganglion cell counts and cross-sectional area determinations at E17.5 and E15.5 show that at E17.5, only 2163 \pm 243 neurons were present in L4 and L5 ganglia from $\operatorname{trk} A(-/-)$ mutant animals compared with $10261 \pm 916$ neurons in controls (a $78.9 \%$ loss). Because reliability of counting may be suspect at early embryonic stages, we determined ganglion section crosssectional areas at E15.5. These measurements revealed a $75 \%$ reduction, suggesting that cell loss was virtually complete even at this early stage.

To determine the time of DRG neuron death in $\operatorname{trk} A(-/-)$ mutants, we assessed ongoing apoptosis in both normal and null mutant animals. Results are shown in Figures 1 and 2. Perhaps surprisingly, apoptotic figures could be detected in normal lumbar DRGs as early as E11.5, a time of active proliferation within the ganglion (Lawson and Biscoe, 1979; S. Ozaki and F. White, unpublished observations). A significant number of labeled figures were also detected at E13.5 and E15.5, suggesting that naturally occurring cell death is ongoing throughout this period.

Determinations of the mean number of apoptotic figures per section in $\operatorname{trk} A(-/-)$ mutant animals as compared with controls revealed a statistically significant increase in the mean number of labeled cells at E11.5. This difference, however, accounts for a relatively small number of apoptotic figures when compared with the $\operatorname{trk} C(-/-)$ and $N T-3(-/-)$ mutant animals (see below). Thus, most DRG neurons at E11.5 are TrkA-independent. In striking contrast, there is massive apoptosis in lumbar DRGs of E13.5 $\operatorname{trk} A(-/-)$ animals. In these ganglia, a mean of 75 apoptotic cells per section exhibit oligosomal DNA fragments. Apoptotic figures represent $36 \%$ of profiles in the ganglion, indicating that most DRG neurons require TrkA for survival at this age. By E15.5, in agreement with volume determinations, death of TrkA neurons in $\operatorname{trk} A(-/-)$ mice seems to be complete. A mean of only two apoptotic DRG cells per section in trk $A(-/-)$ was seen in mutant mice compared with 11 apoptotic cells per section in WT animals.

If NT-3 normally acts via TrkA to support DRG neurons at these early developmental stages, then loss of NGF should not affect survival of ganglion cells until later developmental stages. To compare the onset of dependence on NGF signaling with the dependence on TrkA signaling, we determined the mean number of apoptotic figures per section in $N G F(-/-)$ mutant mice at E13.5 and E15.5. The onset of cell death in lumbar DRGs of $N G F(-/-)$ mutants was strikingly coincidental with that in $\operatorname{trk} A(-/-)$ mutants. Thus, at E13.5, a mean of 79 cells per section exhibited terminal transferase labeling, a figure comparable with that of the $\operatorname{trk} A(-/-)$ mutants. Furthermore, reductions in mean cross-sectional areas of ganglion sections were similar at E13.5 in NGF and TrkA null mutants $(58 \%, n=5 ; 57 \%, n=4$; percentage of WT, respectively), suggesting that the extent of cell death is similar in the two mutants. Finally, at E15.5 the mean number of apoptotic figures in $N G F(-/-)$ animals was 12 per section. This number did not significantly differ from that in WT animals, indicating that almost all NGF-dependent neurons had died by this age. This concurrent onset of NGF and TrkA survival dependence strongly suggests that NT-3 cannot act via TrkA at these early developmental stages to support survival in the absence of NGF.

If current ideas about sensory neurons changing neurotrophin dependence are correct, then there should be differences in the onset of survival dependence between NT-3 and NGF. To compare the onset of NGF/TrkA dependence with the onset of survival dependence on NT-3 and TrkC signaling, we determined the mean number of apoptotic figures per section in $N T-3(-/-)$ and trkC $(-/-)$ mutant mice at E11.5 and E13.5. In contrast to findings in $\operatorname{trk} A(-/-)$ animals, a mean of 30 (21\% of total cell profiles) and 29 (31\% of total cell profiles) apoptotic figures was observed in lumbar DRG sections at E11.5 from NT-3 and trkC null mutants, respectively. Thus, many lumbar DRG cells are dependent on NT-3 and TrkC signaling at this early stage, which is before the onset of TrkA dependence. At E13.5, in NT-3(-/-) mutants, many DRG cells (mean $=54$ cells/section) also exhibit characteristics of apoptosis. This is significantly less than the figure in NGF or TrkA null mutants but is clearly greater than the number of apoptotic profiles in controls. One possible implication is that a substantial percentage of DRG cells require both factors at E13.5. We favor the interpretation, however, that NT-3 dependent cells are late-born cells in the ganglion that have not yet downregulated TrkC (see below).

Interestingly, at E13.5 a discrepancy appears between survival dependence on NT-3 and survival dependence on TrkC. There are significantly fewer apoptotic figures per section $($ mean $=33)$ in $t r k C$ null mutants than in NT-3 null mutants (mean $=54, p<$ 0.007). This difference at E13.5 presumably accounts for the fact that DRG neuron loss is much greater in NT-3 null mutants than in trkC null mutants. One plausible explanation is that many cells in the DRG co-express TrkC and TrkA between E11.5 and E13.5 (see below). Thus NT-3 may act via TrkA in the artificial situation in which TrkC is deficient because of gene targeting.

\section{NT-3 mRNA is abundantly expressed adjacent to DRGs and developing sensory axons at E11.5}

To correlate the onset of dependence on NT-3 and NGF signaling with the availability of neurotrophins, the time course and expression patterns of NGF and NT-3 mRNAs were compared at various developmental stages in $\mathrm{CF}-1$ and $\operatorname{trk} A(+/+)$ mice. Both 

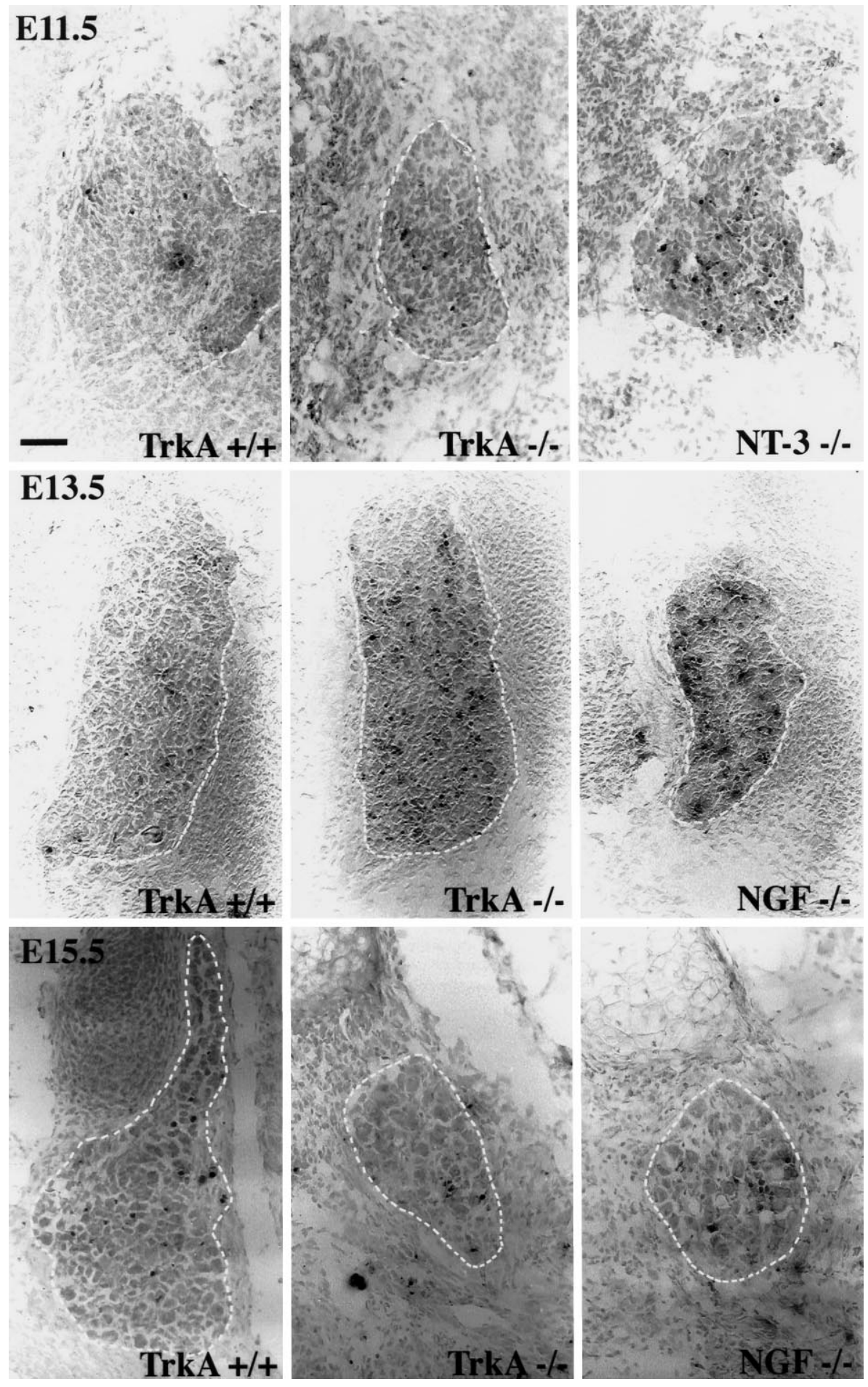

Figure 1. Bright-field photomicrographs showing apoptotic profiles in transverse sections of lumbar ganglia at indicated ages. Note that there is substantial apoptosis in ganglia of NT-3 null mutants but not trkA null mutants at E11.5. There is massive apoptosis at E13.5 in $N G F$ and trk $A$ null mutants, but little in either null mutant by E15.5. Scale bar, $100 \mu \mathrm{m}$.
NGF and NT-3 mRNAs were detectable as early as E10.5, although NT-3 was much more abundant than NGF at this age (not shown). The distributions of NGF and NT-3 mRNA in the hindlimb bud at E11.5 are shown in Figure 3 (top). NT-3 expression (arrows) is diffuse in the dermamyotome adjacent to the DRG and abundant in muscle precursors in the interior of the limb bud. Note that NT-3 expression is particularly intense in the ventral aspect of spinal cord adjacent to the DRG. NGF mRNA is also detectable at E11.5, but is both less abundant and distributed differently than NT-3 mRNA at this age. NGF mRNA expression is restricted to surface ectoderm of the developing hindlimb (arrows).

At E13.5 (Fig. 3, middle), NT-3 mRNA (arrows) is diffusely expressed in all developing paraxial and hindlimb muscle precursors. Additionally, NT-3 mRNA is abundant in the mesenchyme contiguous with the epithelial layer. Signal is present but weaker in the more superficial layers and overlaps with NGF mRNA in this region. Intense expression in the ventral horn adjacent to the DRG is still apparent at this age. In contrast to the pattern for NT-3, there is little NGF expression in the interior of the limb 

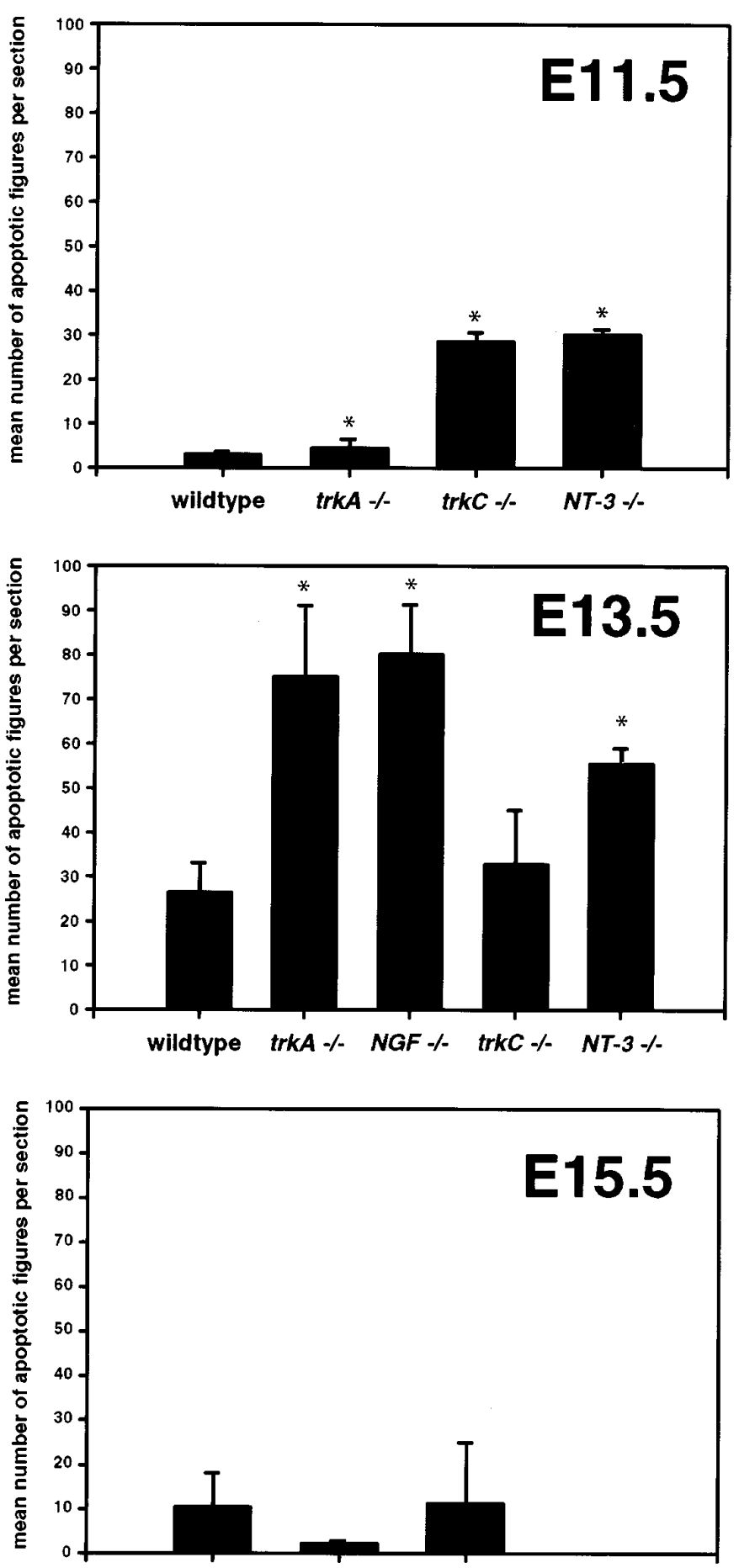

Figure 2. Mean numbers of apoptotic figures per section at E11.5, E13.5, and E15.5 in WT and null mutant mice. Asterisks denote significant differences from WT mice.

bud. NGF mRNA expression is most intense over the developing superficial epithelium (arrows). Interestingly, NGF mRNA was not observable in the distal hindlimb at this age (see below).

By E15.5, NT-3 expression was downregulated (Fig. 3, bottom). NT-3 transcripts (arrows) were still observed, however, in hindlimb muscle precursors and in mesenchyme adjacent to developing epidermis. By PN1, expression in muscle is downregulated further and restricted to developing spindles (not shown; also see
Copray and Brouwer, 1994). In contrast to the pattern for NT-3, increased expression of NGF mRNA transcripts was apparent at E15.5 compared with levels observed at E13.5. NGF transcripts (arrows) were intensely expressed in the epithelium of the hindlimb epidermis and subjacent mesenchyme. NGF mRNA expression was apparent in all but the most distal region of the limb bud at this age.

To assess the possibility that NGF or NT-3 mRNA expression may be upregulated by the loss of TrkA axons, in situ hybridizations were also performed in trkA(-/-) mutants. Although our observations were not quantified, we did not notice obvious differences in the pattern or amount of NGF or NT-3 mRNA expression in these $\operatorname{trk} A(-/-)$ mutant animals. These observations concur with earlier work by Rohrer and colleagues (1988) showing that denervation of developing chick limb buds did not upregulate levels of NGF protein.

\section{TrkA axons from lumbar DRGs do not reach target fields in distal hindlimb until E15}

To correlate target field innervation with neurotrophin mRNA expression, hindlimb innervation by axons of TrkA neurons was studied immunohistochemically using a polyclonal antibody against TrkA (Clary et al., 1995; Molliver and Snider, 1995). This antibody seemed to label DRG axons fully, because growth cones with numerous swellings and complex filopodia were visible (not shown). To assess further the adequacy of TrkA staining for visualizing axons, comparisons with DiI staining were undertaken. DiI labeling revealed somewhat more extensive axon growth at E11.5 and E13.5 (not shown) and may reflect the earlier outgrowth of non-TrkA-expressing axons. Nevertheless, in agreement with data presented below, the most distal hindlimb epithelium was devoid of axons even in DiI-stained material at E13.5.

At E11.5, TrkA-positive fibers are seen penetrating into the central region of the proximal hindlimb, but not extending distally (Fig. 3, top). In more proximal sections (not shown), TrkA axons projecting into dorsal and lateral cutaneous epithelium of the lower trunk were also observed. Centrally, TrkA-positive axons had reached spinal cord but did not penetrate gray matter at this age. Thus, TrkA axons are initially closer to sources of NT-3 than NGF at this age.

TrkA-positive axons first approach cutaneous target fields in proximal hindlimb at E13.5 (Fig. 3, middle); however, note that distal cutaneous targets in the developing hindlimb are clearly not innervated by TrkA axons at this age. The central projections of TrkA-positive fibers at this early embryonic stage are still limited to the dorsal root entry zone and have not penetrated spinal gray matter. Thus, DRG neurons in lower lumbar ganglia have not reached their definitive peripheral or central target fields at E13.5, an age in which massive apoptosis is occurring in lumbar ganglia from $\operatorname{trk} A$ null mutant mice. Note, however, that in the periphery, axons are clearly in proximity to sources of both NGF and NT-3.

By E15.5, the TrkA-positive fibers have reached the most distal portion of the developing hindlimb (Fig. 3, bottom). These TrkApositive fibers arborize extensively in the cutaneous epithelium of the distal hindlimb and are in proximity to areas of intense NGF mRNA expression. Centrally, TrkA axons have also penetrated gray matter at this age (not shown).

\section{Downregulation of TrkC by TrkA neurons}

The expression of TrkA was examined by in situ hybridization and immunohistochemistry in lumbar DRGs of WT animals (Fig. 4). TrkA expression increased steadily between E10.5 and E13.5. 
TrkA mRNA transcripts were detected in a few cells on E10.5, the first day a distinct collection of ganglion cells is apparent (not shown). On E11.5, TrkA mRNA was detected in many DRG cells. Bright-field examination revealed that at least $50 \%$ of DRG cells expressed TrkA transcripts (not shown). Many cells were also strongly immunoreactive for TrkA protein at E11.5 and clearly had the morphology of neurons (Fig. 4, bottom left). By E13.5, most DRG cells expressed substantial amounts of TrkA mRNA and protein. Although not quantitated, it seemed that both the levels of mRNA and the percentage of DRG cells expressing TrkA increased over the $48 \mathrm{hr}$ time period between E11.5 and E13.5. By E15, when percentages can be calculated confidently, it is apparent that both TrkA mRNA and protein are expressed by $\sim 80 \%$ of DRG neurons (Molliver and Snider, 1995).

Expression of the preferred NT-3 receptor TrkC was examined by in situ hybridization in lumbar DRGs at these same ages in WT animals. As reported previously in the developing DRG of chick and rat, TrkC mRNA expression is seen at very early time points (Ernfors et al., 1993; Tessarollo et al., 1993; Oakley et al., 1995). At E11.5, almost all DRG cells intensely express TrkC mRNA (Fig. 4, right). Thus, there must be substantial co-localization of TrkC and TrkA at this age (also see Plouffe et al., 1995). It is important to note that because our probe recognizes mRNA coding, the extracellular domain of TrkC, we are unsure of the ratio or signaling to truncated TrkC isoforms expressed by DRG cells at E11.5.

In striking contrast to the situation with TrkA, most DRG cells downregulate TrkC mRNA expression between E11.5 and E13.5. Both dark-field and bright-field photomicrographs demonstrate that TrkC is expressed by only a minority of DRG cells at E13.5. This pattern of intense expression of TrkC mRNA by a minority of DRG cells persists into adulthood (not shown). Thus, coincidental with the change from NT-3 to NGF dependence, a substantial percentage of DRG neurons downregulate TrkC mRNA expression.

Finally, to determine whether TrkA upregulation accounts for the discrepancy in cell loss between NT-3 and TrkC null mutants, we examined TrkA mRNA expression in DRGs from $t r k C(-/-)$ and WT mice at E11.5 and E13.5. No noticeable differences were detected in patterns or intensity of expression between $\operatorname{trk} C$ null mutants and WT mice (not shown). Thus, absence of TrkC does not lead to alterations of TrkA expression, at least at the mRNA level.

\section{A model of early neurotrophin actions in DRG}

Taking all of our findings into account, we propose the following scenario (Fig. 5). Virtually all neuronal precursors and early postmitotic neurons express TrkC, and many require NT-3/TrkC signaling for survival during the period of active neurogenesis in DRGs (E10.5-E12.5). Consistent with this idea, NT-3 mRNA is abundant in regions immediately adjacent to the developing ganglion and axon projection pathways (also see Buchman and Davies, 1993; Davies, 1994). Although many DRG cells also express TrkA at E11.5, there is little survival dependence on TrkA. By E13.5, axons of the most mature TrkA neurons are projecting into the hindlimb and are in proximity to regions of synthesis of NGF mRNA in developing skin. The onset of TrkA and NGF dependence is synchronous and of equal magnitude at this age, suggesting that the same population of cells requires both molecules. Coincidental with the onset of NGF/ TrkA dependence, TrkC is downregulated by all DRG neurons except proprioceptors, which continue to express TrkC throughout development. Thus, our findings suggest early survival dependence of neuronal precursors, early postmitotic neurons, and fully differenti- ated proprioceptors on locally synthesized NT-3 at E11.5, and a shift to dependence on skin-derived NGF by postmitotic TrkA-expressing neurons at E13.5. Furthermore, our findings provide no support for the idea that NT-3 acts via TrkA under normal conditions. Finally, it is important to point out that our results speak only to the onset of neurotrophin and Trk survival dependence. TrkA- and TrkCexpressing subpopulations continue to require their appropriate target-derived neurotrophin throughout much of embryonic development (Ruit et al., 1992; Oakley et al., 1995).

Of note is that the discrepancy between the amount of cell death in DRGs between $N T-3(-/-)$ and trkC $(-/-)$ mutants is apparent at E13.5. Our findings of extensive expression of both TrkC and TrkA in the DRG at E11.5 suggest that many early postmitotic neurons express both of these receptors (also see Plouffe et al., 1995). Therefore it seems plausible that NT-3 acts via TrkA in the artificial situation in which TrkC is absent. These results underscore the need for careful interpretation of absence of findings in null mutant mice because of the possibility of nonphysiological compensation.

\section{DISCUSSION}

\section{Dependence of precursors and early postmitotic neurons on NT-3}

The dependence of DRG cells on NT-3/TrkC signaling at E11.5 reported here corresponds nicely with the previously reported results of Tessarollo and colleagues (1994) that much of the TrkC population was depleted by E11.5 in NT-3(-/-) mice. These findings are also fully consistent with previous in vitro demonstrations of survival dependence of neuronal precursors on NT-3 (Birren et al., 1993; DiCicco-Bloom et al., 1993), even though these studies relate to sympathetic rather than sensory neuroblasts. Thus, the onset of NT-3 and TrkC dependence is E11.5, which is at the height of neurogenesis in mouse DRGs (roughly E10.5-E12.5) (Lawson and Biscoe, 1979; S. Ozaki and F. White, unpublished observations). Because $\sim 30 \%$ of cell profiles exhibit signs of apoptosis at E11.5 in NT-3(-/-) and trkC $(-/-)$ animals, it seems likely that some of the NT-3-dependent cells are actively dividing. Interestingly, previous studies have shown that NT-3 also affects proliferation of sympathetic precursors in vitro (Verdi and Anderson, 1994; also see Ockel et al., 1996). Our findings of massive apoptosis in DRGs at E11.5 in NT-3(-/-) and $\operatorname{trkC}(-/-)$ mutants argue that the predominant requirement for NT-3 in vivo is for ganglion cell survival. We cannot exclude the possibility, however, that proliferation may be regulated by NT-3 before the onset of survival dependence at E11.5.

It is clear that NT-3 must also support postmitotic neurons at these early stages for two reasons. First, the entire proprioceptive population is lost before E13.5 in the absence of NT-3 (Kucera et al., 1995). These are thought to be the earliest-born cells in the DRG (Lawson and Biscoe, 1979) and thus must be postmitotic during the height of NT-3/trkC dependence at E11.5. Second, many DRG cells at E13.5 also require NT-3 for survival. These are most likely early postmitotic cells that are in the process of upregulating TrkA and downregulating TrkC. This interpretation is consistent with the findings of Buchman and Davies, (1993), who showed that murine trigeminal ganglion neurons at E10-E12 can be supported by NT-3. Over a $48 \mathrm{hr}$ period between E11 and E13, these neurons lose the ability to survive in the presence of this factor and become dependent on NGF. Presumably this population of postmitotic neurons requires NT-3 for survival during this same period in vivo.

Our findings of extensive expression of NT-3 mRNA in regions 


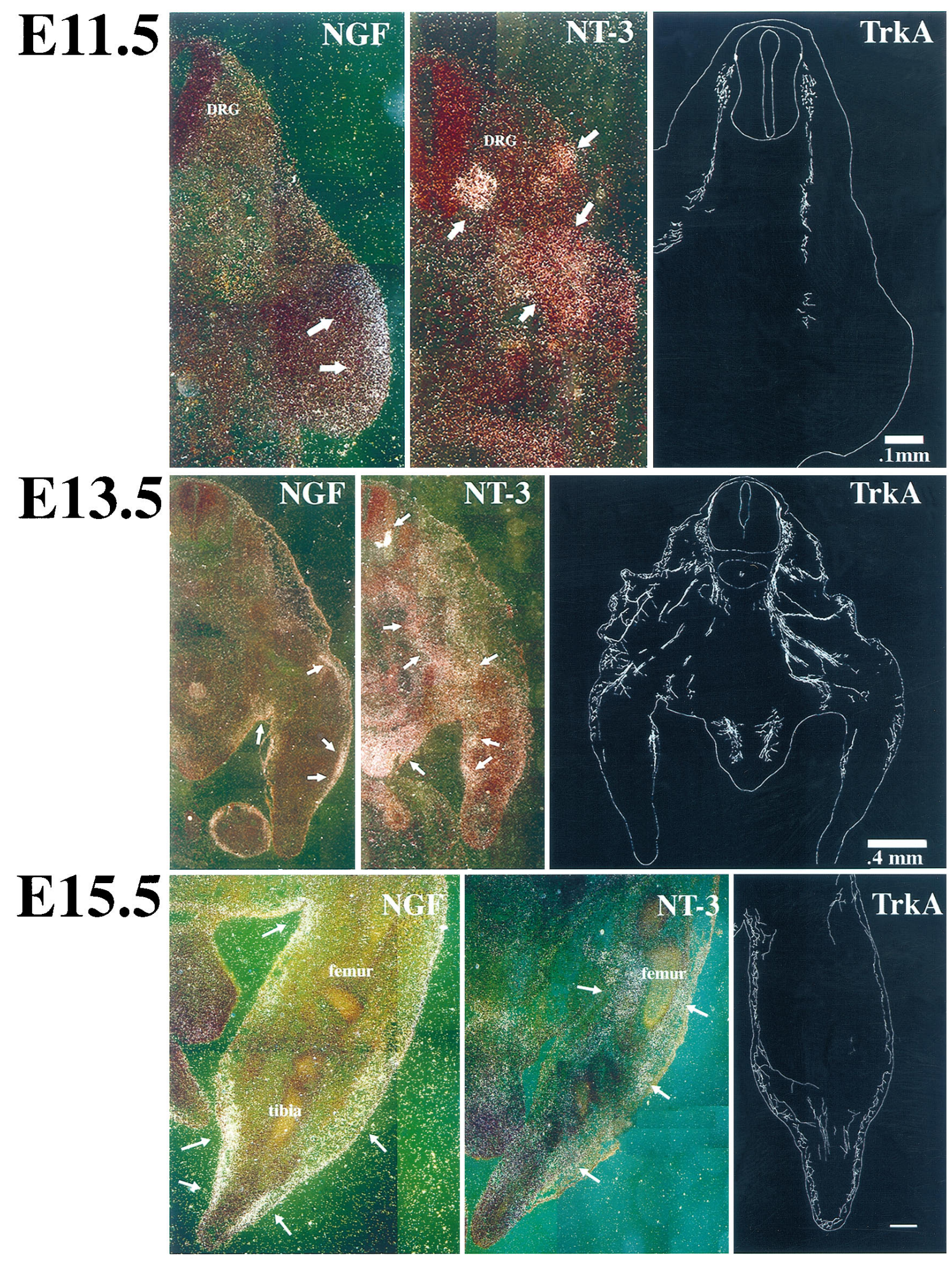


immediately adjacent to the ganglion at E11.5 are consistent with the survival requirement for NT-3/TrkC signaling at this age. Previously, Northern blots had revealed that BDNF and NT-3 were expressed in peripheral tissues at an earlier age than NGF (Buchman and Davies, 1993). Consistent also with important early functions for NT-3 is that NT-3 expression has been documented in chick and rat neural tube, differentiating motor neurons and dermamyotome, and even within the DRG (Ernfors and Persson, 1991; Kalcheim et al., 1992; Pinco et al., 1993; Schecterson and Bothwell, 1992; Elkabes et al., 1994; Brill et al., 1995). In accord with this early NT-3 expression adjacent to sensory axons, we find widespread expression of TrkC in DRGs at E11.5 (also see Ernfors et al., 1993; Tessarollo et al., 1993; for data in chick, see Williams and Ebendal, 1995; Kahane and Kalcheim, 1994). Because of extensive neurogenesis within the ganglion at this age, almost certainly both precursors and early postmitotic cells are included. A surprising feature of our findings, however, is that TrkA mRNA and protein expression are also extensive at E11.5. Thus, many cells must express both TrkA and TrkC at this age. Consistent with this interpretation is the recent finding in chick that $\mathrm{TrkC}$ is transiently expressed by cutaneous sensory axons at early developmental stages (Plouffe et al., 1995).

The most striking feature of these patterns of receptor expression is the massive downregulation of TrkC mRNA between E11.5 and E13.5. Downregulation of TrkC in sensory ganglia has also been demonstrated previously in rat and chick (Ernfors et al., 1993; Zhang et al., 1994; Williams and Ebendal, 1995). It is obviously attractive to consider this downregulation, presumably in a population of TrkA-expressing neurons, as being responsible for the switch from NT-3/TrkC dependence at E11.5 to NGF/ TrkA dependence at E13.5.

\section{Synchronous onset of NGF and TrkA survival dependence}

Results of sensory neuron loss in sympathetic and dorsal root ganglia have differed greatly in $N T-3(-/-)$ and trkC $(-/-)$ mutant mice. Although neuronal counting is fraught with uncertainty (see Saper, 1996), it is clear that sensory and sympathetic cell loss is far greater in $N T-3(-/-)$ than in $\operatorname{trkC}(-/-)$ mutants. For example, DRG loss in trkC(-/-) mutants is reported to be $20 \%$ (Klein et al., 1994; Minichiello et al., 1995; Silos-Santiago et al., 1995), compared with up to $75 \%$ in NT-3(-/-) mutants (Ernfors et al., 1994; Fariñas et al., 1994). Furthermore, in contrast to NT-3(-/-) mutants, no sympathetic ganglion cell loss occurs in $\operatorname{trkC}(-/-)$ mutants (Silos-Santiago et al., 1995). These discrepancies have lead to the idea that NT-3 may signal via TrkA at early developmental stages and support large percentages of TrkA-expressing neurons via this mechanism (Fariñas et al., 1994). Indeed, ample evidence supports the concept that NT-3 can act via TrkA in vitro (Ip et al., 1993; Davies et al., 1995).

We show here that the onset of survival dependence on NGF and TrkA is concurrent at E13.5, $48 \mathrm{hr}$ after the onset of NT-3/ TrkC dependence. This concurrent onset of survival dependence of NGF and TrkA provides no support for the idea that NT-3 acts via TrkA during normal development. If NT-3 were supporting neurons via TrkA at early stages, one would expect the loss in $\operatorname{trk} A(-/-)$ mutants to occur earlier than in $N G F(-/-)$ mutants. It is important to note that some DRG cells are dependent on NT-3 at E13.5. Thus, it could be argued that both NT-3 and NGF act via TrkA at this age. In this scenario, however, apoptosis in $\operatorname{trk} A(-/-)$ mutants should be twice as extensive as apoptosis in either $N G F(-/-)$ or $N T-3(-/-)$ mutants. In fact, the magnitude of loss in $\operatorname{trk} A(-/-)$ mutants at E13.5 as judged by absolute numbers of apoptotic cells and reduction in ganglion section cross-sectional areas is almost identical to the loss in $N G F(-/-)$ mutants, both of which argue that NT-3 is not acting via TrkA. The most likely explanation is that NT-3 supports a population of early postmitotic cells that still express TrkC at E13.5.

It is perhaps surprising that NT-3 cannot support DRG neurons via actions on TrkA at E13.5, because TrkA axons are in proximity to sources of NT-3. Concentrations of NT-3 possibly are not adequate, because activation of TrkA by NT-3 requires relatively high concentrations of NT-3 compared with NGF (Birren et al., 1993; Davies et al., 1993; Dechant et al., 1993; DiCicco-Bloom et al., 1993; Davies et al., 1995). Also, expression of p75 is robust in many DRG neurons by E13 (F. White, unpublished observations) and may prevent activation of TrkA by NT-3 (Ip et al., 1993). A potential explanation for the discrepancy between survival in $N T-3(-/-)$ and trkC(-/-) mutant animals at E13.5 is that NT-3 acts via TrkA in the highly abnormal situation where no TrkC receptor is present. It seemed plausible that TrkA might be upregulated in the setting of TrkC deficiency, but our preliminary studies provide no support for this concept. Finally, it remains possible that NT-3 signals via the preferred BDNF/NT-4 receptor TrkB at early developmental stages, a possibility not addressed by this study.

The extent of DRG neuron loss in NGF and NT-3 null mutant mice reveals that as many as $40 \%$ of DRG neurons require the actions of both NT-3 and NGF during development (Fariñas et al., 1994; Airaksinen et al., 1996; for studies in chick, see Gaese et al., 1994). It is important to point out that NT-3 supports a population of non-TrkA-expressing TrkC neurons that are proprioceptors (Ernfors et al., 1994; Fariñas et al., 1994; Klein et al., 1994). Because these cells comprise only $18 \%$ of DRG neurons (Klein et al., 1994), however, the majority of TrkA neurons $(80 \%$

Figure 3. Dark-field photomicrographs of the distributions of NGF and NT-3 mRNA expression in transverse sections through the lumbar spinal cord and hindlimb of an E11.5, E13.5, and E15.5 mouse embryo. Right panels are camera lucida reconstructions of TrkA-immunoreactive axons at corresponding time points. At E11.5, note that NGF mRNA expression (arrows) is limited to the developing epithelium. In contrast, NT-3 mRNA transcripts (arrows) are distributed throughout the dermamyotome and muscle precursors of the developing hindlimb. Note intense expression of NT-3 mRNA in the ventral horn of the developing spinal cord (arrow) adjacent to the DRG. TrkA-IR-labeling demonstrates that TrkA-IR axons have penetrated only the proximal region of the limb bud at this age. Note that TrkA axons would likely be exposed to high concentrations of NT-3 all along their course at E11.5. Scale bars, $100 \mu \mathrm{m}$. At E13.5, NGF mRNA (arrows) is limited to developing epithelium of the proximal hindlimb. NT-3 mRNA (arrows) is still expressed in ventral horn and muscle precursors but is now also expressed in developing epithelium and gonads. TrkA-IR axons have reached the surface epithelium of the proximal hindlimb at this age but do not project into distal hindlimb. Note that there is a rough correspondence between the proximodistal extent of NGF expression and the proximodistal extent of TrkA axon extension. Thus at E13.5, TrkA axons would likely be exposed to both NT-3 and NGF. Scale bar, $400 \mu \mathrm{m}$. At E15.5, expression of NGF mRNA (arrows) is more intense than at earlier stages. Expression remains superficial in the epithelial layer and superficial mesenchyme and has extended to all regions of the limb bud except the most distal tip. In contrast, NT-3 transcripts (arrows) clearly have been downregulated, although the pattern of NT-3 expression remains the same as at earlier stages. Extensive innervation of epithelium in the distal hindlimb by TrkA-IR axons is apparent by E15.5. Scale bar, $300 \mu \mathrm{m}$. 

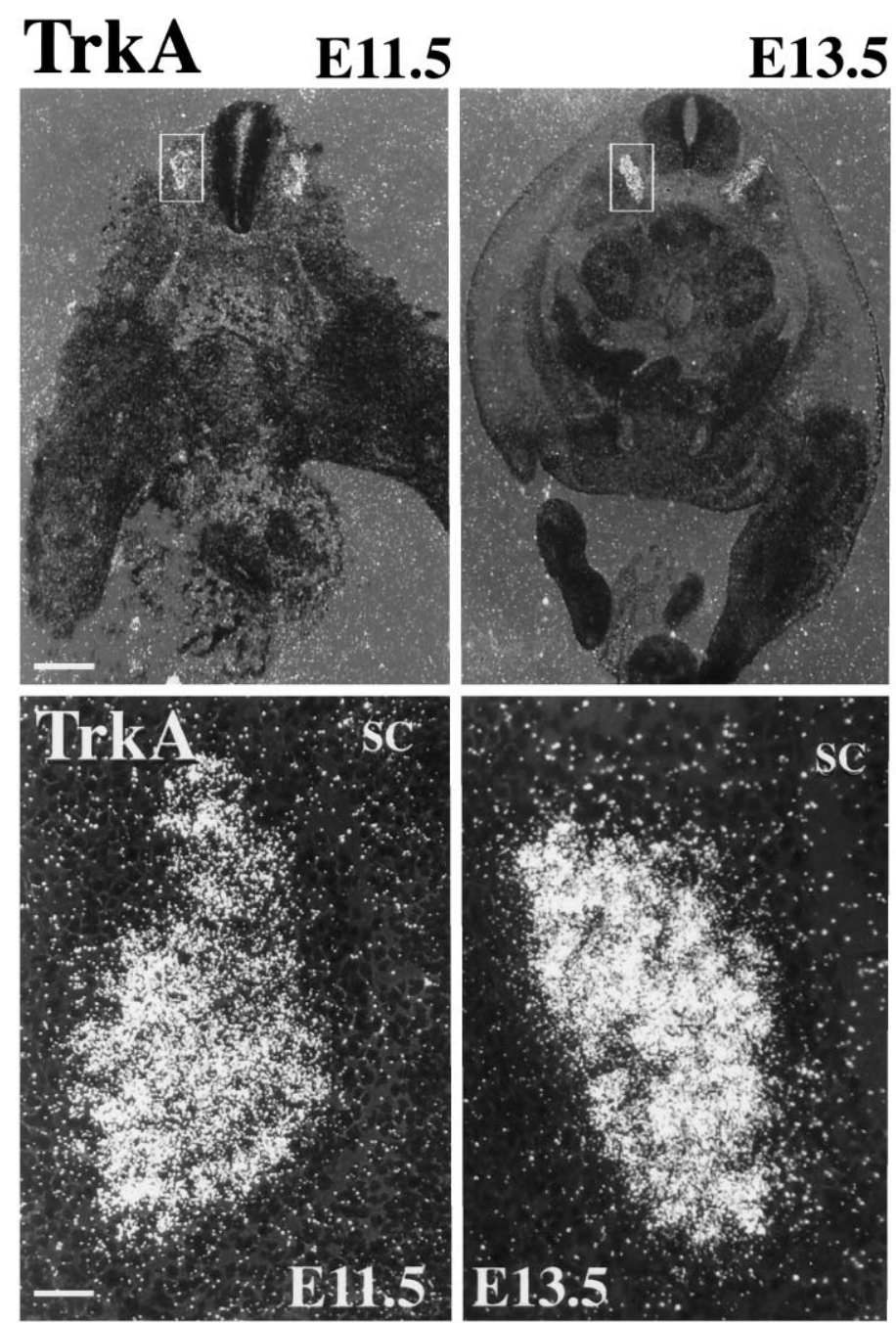

E13.5 TrkC E11.5

E13.5
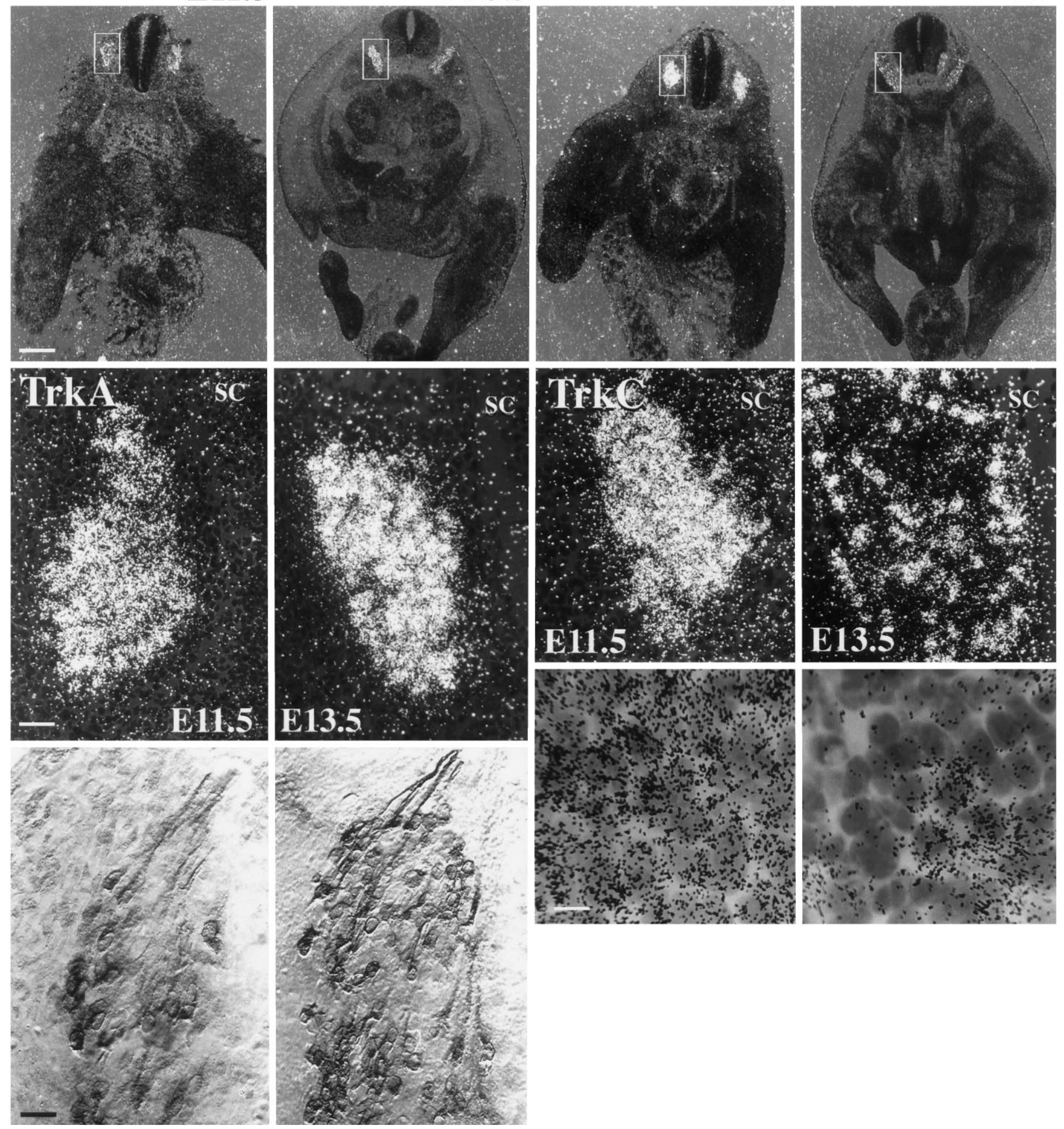

Figure 4. TrkA and TrkC expression in lumbar DRGS at E11.5 and E13.5. Left, TrkA (top), Low-power dark-field photomicrographs of transverse sections through the hindlimb region at E11.5 and an E13.5 hybridized with antisense TrkA riboprobe. Dashed box shows DRG. Note that expression is already apparent at E11.5 and increases by E13.5. Scale bar, $500 \mu \mathrm{m}$. Middle, Higher power of box shows that most DRG cells express TrkA at E11.5 and E13.5 and that mRNA levels increase between the two time points. $S C$, Spinal cord. Scale bar, $100 \mu \mathrm{m}$. Bottom, Bright-field photomicrographs (Nomarski) of TrkA immunoreactivity. Many DRG cells clearly express TrkA protein as early as E11.5. Scale bar, $100 \mu \mathrm{m}$. TrkC (top), TrkC mRNA is intensely expressed by DRG cells at E11.5. In striking contrast to the pattern for TrkA expression, TrkC mRNA is downregulated by most DRG cells between E11.5 and E13.5. Middle, Higher magnification of boxed regions demonstrates downregulation of TrkC by many DRG cells. Bottom, 100× bright-field photomicrographs show that $>80 \%$ of DRG cells express TrkC at E11.5, whereas only a minority express TrkC at E13.5. Scale bar, $40 \mu \mathrm{m}$. 

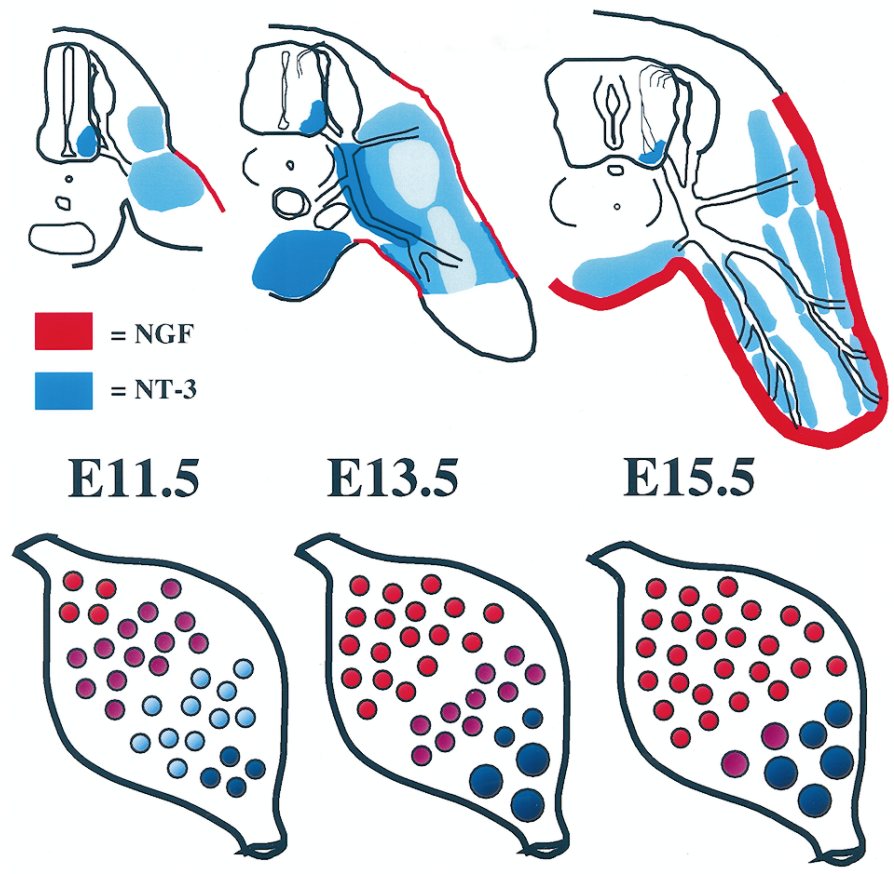

E13.5

E15.5
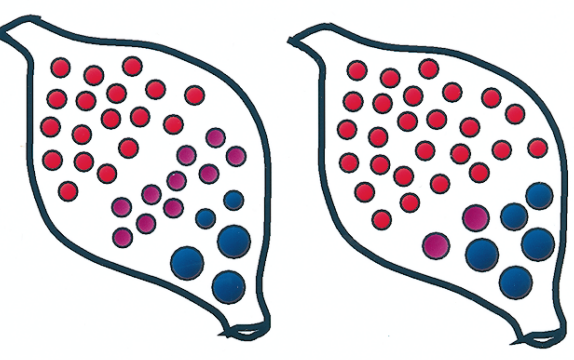

\begin{tabular}{llr} 
& Trk & NT-depen \\
\cline { 2 - 3 } & TrkC & NT-3 \\
TrkC & NT-3 \\
TrkC/TrkA & NT-3 \\
TrkA & NGF
\end{tabular}

Stage

Precursor

Post-mitotic

Post-mitotic

Post-mitotic

Figure 5. Schematics of lumbar DRG axon projections in relation to neurotrophin expression (top) and changes in neurotrophin receptor expression and neurotrophin dependence in lumbar DRGs (bottom) at E11.5-E15.5. For the sake of clarity, hindlimbs in top and DRGs in bottom are not drawn to scale.

of DRG neurons at early stages) are supported by NT-3 between E11.5 and E13.5. The onset of NGF/TrkA dependence $48 \mathrm{hr}$ after the onset of NT-3/TrkC dependence establishes that NT-3 and NGF act sequentially to regulate development of these TrkAexpressing neurons. Interestingly, some TrkA neurons survive in NT-3(-/-) mutants and thus may not require NT-3 signaling (Ernfors et al., 1994; Fariñas et al., 1994; Airaksinen et al., 1996). One cannot exclude the possibility, however, that all TrkA neurons normally may be supported by NT-3 during development, but that compensation may occur via NGF/TrkA or BDNF/TrkB in the NT-3(-/-) mutants.

\section{DRG neuron death in relation to arborization of sensory axons in target fields}

Current thinking about dependence of neurons on locally synthesized neurotrophins at early developmental stages would suggest that neurons switch to dependence on target-derived factors after arrival of axons in their definitive target fields (Davies, 1994). Thus, the onset of dependence on NGF/TrkA signaling shown in this study is a surprisingly early phenomenon. Indeed, lower lumbar DRG neurons in NGF and TrkA null mutant mice die massively at E13.5, $48 \mathrm{hr}$ before the time that their axons arborize in the superficial ectoderm of the distal hindlimb. Our results thus demonstrate the puzzling phenomenon that neurons are depen- dent on signaling from a target-derived factor well before arrival of axons in the definitive target field. These observations are entirely in agreement with the results of Coggeshall and colleagues (1994) who found that naturally occurring cell death in L4-L5 lumbar DRGs in the rat was ongoing several days before arrival of axons in the distal hindlimb as revealed by GAP-43 staining. Recently reported results in vestibular ganglia in trkBdeficient animals also suggest the death of many neurons before the arrival of axons in the sensory epithelium of the inner ear (Fritsch et al., 1995; Schimmang et al., 1995).

The most logical explanation for this early dependence of sensory axons on skin-derived NGF is that axons are in proximity to sources of diffusible NGF in the hindlimb well before they reach their final fields of innervation. Indeed, Figure 3 demonstrates that the proximodistal extent of NGF mRNA expression is roughly correlated with the proximodistal extent of TrkA axon projections into the limb bud between E13.5 and E15.5. Furthermore, growing TrkA axons are located superficially, apparently in close proximity to cutaneous regions of NGF mRNA synthesis. The most interesting question here is how these DRG neurons switch from NT-3 to NGF dependence. In particular, what signals initiate the downregulation of TrkC mRNA and upregulation of TrkA mRNA by DRG neurons as axons arrive in proximity to sources of NGF?

It is important to place these results in the context of current ideas about the regulation of naturally occurring cell death by competition for neuronal growth factors synthesized by target tissues (Oppenheim, 1991). It is apparent that regulation of neuronal survival at early developmental stages is considerably more complex than has been appreciated previously. The work reported here indicates that the survival of precursors and early postmitotic neurons is regulated by growth factors well before any influences from targets, and that naturally occurring death happens during this early period. It should be emphasized, however, that naturally occurring cell death continues well after initial arrival of axons in target fields. We find substantial apoptosis at E15.5 in WT animals, a time when sensory axons are arborizing throughout the cutaneous epithelium of the hindlimb in proximity to sources of NGF (also see Coggeshall et al., 1994). Thus, our findings in no way invalidate ideas about regulation of cell number related to competition of axons for target-derived factors. Indeed, a decline of neuronal number after this time would make an important contribution to the final neuron count.

\section{REFERENCES}

Airaksinen MS, Koltzenburg M, Lewin GR, Masu Y, Helbig C, Wolf E, Brem G, Toyka KV, Thoenen H, Meyer M (1996) Specific sub-types of cutaneous mechanoreceptors require neurotrophin-3 following peripheral target innervation. Neuron 16:287-295.

Birren SJ, Liching L, Anderson DJ (1993) Sympathetic neuroblasts undergo a developmental switch in trophic dependence. Development 119:597-610.

Brill G, Kahane N, Carmelli C, von Schack D, Barde YA, Kalcheim C (1995) Epithelial-mesenchyme conversion of dermatome progenitors requires neural tube-derived signals: characterization of the role of neurotrophin-3. Development 121:2583-2594.

Buchman VL, Davies AM (1993) Different neurotrophins are expressed and act in a developmental sequence to promote the survival of embryonic sensory neurons. Development 118:989-1001.

Bujo-Bello A, Pinon LGP, Davies AM (1994) The survival of NGFdependent but not BDNF-dependent cranial sensory neurons is promoted by several different neurotrophins early in their development. Development 120:1573-1580.

Clary DO, Weskamp G, Austin LAR, Reichardt LF (1995) TrkA crosslinking mimics neuronal responses to nerve growth factor. Mol Biol Cell 5:549-563. 
Coggeshall RE, Pover CM, Fitzgerald M (1994) Dorsal root ganglion cell death and surviving cell numbers in relation to the development of sensory innervation in the rat hindlimb. Dev Brain Res 82:193-212.

Copray JC, Brouwer N (1994) Selective expression of neurotrophin-3 messenger RNA in muscle spindles of the rat. Neuroscience 63:1125-1135.

Crowley C, Spencer SD, Nishimura MC, Chen KS, Pitts-Meek S, Armanini MP, Ling LH, McMahon SB, Shelton DL, Levinson AD, Phillips HS (1994) Mice lacking nerve growth factor display perinatal loss of sensory and sympathetic neurons yet develop basal forebrain cholinergic neurons. Cell 76:1001-1011.

Davies AM (1994) Switching neurotrophin dependence. Curr Biol 4:273-276.

Davies AM, Lee K-F, Jaenisch R (1993) p75-deficient trigeminal sensory neurons have an altered response to NGF but not to other neurotrophins. Neuron 11:565-574.

Davies AM, Minichiello L, Klein R (1995) Developmental changes in NT-3 signalling via TrkA and TrkB in embryonic neurons. EMBO J 14:4482-4489.

Dechant G, Rodriguez-Tebar A, Kolbeck R, Barde YA (1993) Specific high-affinity receptors for neurotrophin-3 on sympathetic neurons. J Neurosci 13:2610-2616.

DiCicco-Bloom E, Friedman WJ, Black IB (1993) NT-3 stimulates sympathetic neuroblast proliferation by promoting precursor survival. Neuron 11:1101-1111.

Elkabes SC, Drefus D, Schaar D, Black IB (1994) Embryonic sensory development: local expression of NT-3 and target expression of nerve growth factor. J Comp Neurol 341:204-213.

Ernfors P, Persson H (1991) Developmentally regulated expression of HDNF/NT-3 in rat spinal cord motoneurons and expression of BDNF mRNA in embryonic dorsal root ganglion. Eur J Neurosci 3:953-961.

Ernfors P, Rosario CM, Merlio J-P, Grant G, Aldskogius H, Persson H (1993) Expression of mRNAs for neurotrophin receptors in the dorsal root ganglion and spinal cord during development and following peripheral or central axotomy. Mol Brain Res 17:217-223.

Ernfors P, Lee K-F, Kucera J, Jaenisch R (1994) Lack of neurotrophin-3 leads to deficiencies in the peripheral nervous system and loss of limb proprioceptive afferents. Cell 77:503-512.

Ernfors P, Van De Water T, Loring J, Jaenisch R (1995) Complementary roles of BDNF and NT-3 in vestibular and auditory development. Neuron 14:1153-1164.

Fariñas I, Jones K, Backus C, Wang X, Reichardt LF (1994) Severe sensory and sympathetic deficits in mice lacking NT-3. Nature 369:658-661.

Fritsch B, Fagan AM, Smeyne R, Silos-Santiago I (1995) Reduction and loss of inner ear innervation in trkB and trkC receptor knockout mice. Soc Neurosci Abstr 21:780.4.

Gaese F, Kolbeck R, Barde YA (1994) Sensory ganglia require neurotrophin-3 early in development. Development 120:1613-1619.

Ip NY, Stitt TN, Tapley P, Klein R, Glass DJ, Fandl J, Greene LA, Barbacid M, Yancopoulos GD (1993) Similarities and differences in the way neurotrophins interact with Trk receptors in neuronal and nonneuronal cells. Neuron 10:137-149.

Kahane N, Kalcheim C (1994) Expression of trkC receptor mRNA during development of the avian nervous system. J Neurobiol 25:571-584.

Kalcheim C, Carmeli C, Rosenthal A (1992) NT-3 is a mitogen for cultured neural crest cells. Proc Natl Acad Sci USA 89:1661-1665.

Klein R (1994) Role of neurotrophins in mouse neuronal development. FASEB J 8:738-744.

Klein R, Silos-Santiago I, Smeyne RJ, Lira SA, Brambilla R, Bryant S, Zhang L, Snider WD, Barbacid M (1994) Disruption of the neurotrophin-3 gene trkC eliminates Ia muscle afferents and results in abnormal movements. Nature 368:249-251.

Kucera J, Fan G, Jaenisch R, Linnarsson S, Ernfors P (1995) Dependence of developing group Ia afferents on neurotrophin-3. J Comp Neurol 363:307-320.

Lawson SN, Biscoe TJ (1979) Development of mouse dorsal root ganglion: an autoradiographic and quantitative study. J Neurocytol 8:265-274.

Minichiello L, Piehl F, Vazquez E, Schimmang T, Hokfelt T, Represa J, Klein R (1995) Differential effects of combined trk receptor mutations on dorsal root ganglion and inner ear sensory neurons. Development 121:4067-4075.
Molliver DC, Snider WD (1995) TrkA is downregulated during postnatal development by a subset of dorsal root ganglion neurons. Soc Neurosci Abstr 21:515.2.

Mu X, Silos-Santiago I, Carroll SL, Snider WD (1993) Neurotrophin receptor genes are expressed in distinct patterns in developing dorsal root ganglia. J Neurosci 9:4029-4041.

Oakley RA, Garner AS, Large TH, Frank E (1995) Muscle sensory neurons require NT-3 from peripheral tissues during normal cell death. Development 121:1341-1350.

Ockel M, Lewin GR, Barde YA (1996) In vivo effects of neurotrophin-3 during sensory neurogenesis. Development 122:301-307.

Oppenheim RW (1991) Cell death during development of the nervous system. Annu Rev Neurosci 14:453-501.

Pinco O, Carmeli C, Rosenthal A, Kalcheim C (1993) Neurotrophin-3 affects proliferation and differentiation of distinct neural crest cells and is present in the early neural tube of avian embryos. J Neurobiol 24:1626-1641.

Plouffe PJ, Oakley RA, Lefcort FB, Clary DO, Reichardt LF, Frank E (1995) Expression of trkC in cutaneous nerves during embryogenesis. Soc Neurosci Abstr 21:33.

Rohrer H, Heumann R, Thoenen H (1988) The synthesis of nerve growth factor (NGF) in developing skin is independent of innervation. Dev Biol 128:240-244.

Ruit KG, Elliot JL, Osbourne PA, Yan Q, Snider WD (1992) Selective dependence of mammalian DRG neurons on nerve growth factor during embryonic development. Neuron 8:573-587.

Saper CB (1996) Anyway you cut it: a new journal policy for the use of unbiased counting methods. J Comp Neurol 364:5.

Schecterson LC, Bothwell M (1992) Novel roles for neurotrophins are suggested by BDNF and NT-3 mRNA expression in developing neurons. Neuron 9:449-463.

Schimmang T, Minichiello L, Vazquez E, San Jose I, Giraldez F, Klein R, Represa J (1995) Developing inner ear sensory neurons require TrkB and TrkC receptors for innervation of their peripheral targets. Development 121:3381-3391.

Silos-Santiago I, Molliver DC, Zhang L, Gerfen RW, Dhar-Karihaloo M, Smeyne RJ, Barbacid M, Snider WD (1994) Subsets of primary sensory neurons die early in embryonic development in the trkA KO mice. Soc Neurosci Abstr 20:238.

Silos-Santiago I, Molliver DC, Ozaki S, Smeyne RJ, Fagan AM, Barbacid M, Snider WD (1995) Non-TrkA-expressing small DRG neurons are lost in TrkA deficient mice. J Neurosci 15:5929-5942.

Smeyne RJ, Klein R, Schnapp A, Long LK, Bryant S, Lewin A, Lira SA, Barbacid M (1994) Severe sensory and sympathetic neuropathies in mice carrying a disrupted Trk/NGF receptor gene. Nature 368:246-249.

Snider WD (1994) Functions of the neurotrophins during nervous system development: what the knockouts are teaching us. Cell 77:627-638.

Tessarollo L, Tsoulfas P, Martin-Zanca D, Gilbert DJ, Jenkins NA, Copeland NG, Parada LF (1993) TrkC, a receptor for neurotrophin-3, is widely expressed in the developing nervous system and in nonneuronal tissues. Development 118:463-475.

Tessarollo L, Vogel KS, Palko ME, Reid SE, Parada LF (1994) Targeted mutation in the neurotrophin-3 gene results in loss of muscle sensory neurons. Proc Natl Acad Sci USA 91:11844-11848.

Verdi JM, Anderson DJ (1994) Neurotrophins regulate sequential changes in neurotrophin receptor expression by sympathetic neuroblasts. Neuron 13:1359-1372.

Williams R, Ebendal T (1995) Neurotrophin receptor expression during development of the chick spinal sensory ganglion. NeuroReport 6:2277-2282

Wright DE, Snider WD (1995) Neurotrophin receptor mRNA expression defines distinct populations of neurons in rat dorsal root ganglion. J Comp Neurol 351:329-338.

Wright DE, White FA, Gerfen RW, Silos-Santiago I, Snider WD (1995) The guidance molecule semaphorin III is expressed in regions of spinal cord and periphery avoided by growing sensory axons. J Comp Neurol 361:321-333

Zhang D, Lihua Y, Bernd P (1994) Expression of trk and neurotrophin mRNA in dorsal root and sympathetic ganglia of the quail during development. J Neurobiol 25:1517-1532. 